\title{
EFFECT OF LARVAL COLLECTING SYSTEM ON THE SPAWNING EFFICIENCY AND QUALITY OF SEX REVERSED FRY IN TILAPIA FISH HATCHERIES
}

\author{
R.M. Abou Zied \\ Faculty of Agriculture, Fayoum University, Egypt
}

\section{SUMMARY}

The present study was conducted to evaluate the effects of larval production system on the spawning efficiency and quality of Nile tilapia seeds produced in commercial hatcheries. This study was performed through two stages (spawning and larval rearing). Three treatments were performed during the spawning stage as follows: (1) larvae collected from hatching Laboratory lab. after egg hatching every 10-12 days; (2) larvae collected from hapa every 10-12 days and (3) larvae collected from brood's mouth every 4-5 days. Each treatment was performed in 5 hapas. One thousand and eight hundred brood fish were divided equally on fifteen hapas located in broodstock earthen pond. Each hapa was stocked with 120 broodstocks (90 Female +30 male) at a rate of $5 \mathrm{fish} / \mathrm{m}^{3}$. The average weight of each broodstock was $125 \pm 7.8 \mathrm{~g}$. Broodstocks were fed on a commercial diet contained $29.89 \%$ protein (produced by Hendrix Company, Egypt) at a rate of $2 \%$ of body weight,two meals daily except the days of eggs and/or larvae collection. The collected larvae from the previous treatment weretreated with a high dose of hormone (17 -methyltestosterone (MT) at $100 \mathrm{mg} / \mathrm{kg}$ diet for 21 days (larval rearing stage). The results revealed that the spawning performance was improved significantly with larvae collected from brood's mouth system every 4-5 days than those collected directly from hapa or incubated eggs in the laboratory every 10-12 days by about 196 and 148\%, respectively. Larvae number/female/year was 2222, 1680 and 3298 larvae for collected system from laboratory, hapa and brood's mouth, respectively. The highest percentage of male was obtained for larvae collected from brood's mouth (96.61\%) followed by larvae hatched in laboratory. (96.15\%) and larvae collected from hapa (90.33\%). The total production cost of fish fry collected from hatchery laboratory was higher than other systems. Percentages of net profit to total cost were 36.54; 24.88 and $94.67 \%$ for hatchery collected larvae from laboratory., hapa and brood's mouth, respectively. Sensitivity analysis showed that the three larvae collecting systems would still generate positive net returns even if sales prices decreased by $10 \%$ and variable costs increased by $10 \%$. However when sales prices decreased $30 \%$ and total costs were increased by 30\%, only the larvae collected from brood's mouth system could still be positive, while the larvae collecting system from laboratory and hapa showed losses.

Based on the obtained results, the collected larvae from brood's mouth in hapas every 4-5 days intervals could be recommended for Nile tilapia commercial hatcheries.

\section{Keywords: Nile tilapia, spawning efficiency, sex reversal, economic efficiency}

\section{INTRODUCTION}

Egypt was ranked in the ninth status in the global production of fish from aquaculture and the twelfth in the production of natural resources FAO (2014). Fish production from aquaculture activities contributed $74 \%$ of the total fish production which amounts to 1.305 million metric tons, constituting $63.48 \%$ of them. The fisheries sector contributed $8.5 \%$ in national agriculture income. The exploited area in Fish farms in Fayoum Governorate was 2750 feddans besides 12 fish hatcheries (GAFRA, 2012).

Globally, Tilapias are currently the second most important farmed fish species (behind carps).As a result, the global production of farmed tilapia has increased from 383,654 metric tons (mt) in 1990 representing $4.5 \%$ of the total farmed fish production to $3,497,391 \mathrm{mt}$ in 2010 , representing $8.9 \%$ of the total farmed fish production, with an average annual growth of $13.5 \%$ (FAO, 2012). This trend has created a gap between seed supply and farmer's demand. Therefore, the major challenge facing tilapia culture industry is the production of sufficient amounts of high quality seeds. Tilapias are a hardy species produced by several culture methods under a wide range of environmental conditions in tropical and subtropical regions in the developing countries and can be cultured in mesh cages that maintains good circulation of water. It ensures the flexibility in management practices with easy and low cost of harvesting.

The production of mono-sex (all-male) tilapia played a significant role in facing this challenge, due to their fast growth rates, tolerance of a wide range of environmental conditions, resistance to stress and diseases, higher energy conservation, reduced aggressiveness and greater uniformity of size at harvest (El-Sayed, 2006).Although mono-sex male population can be obtained by direct or indirect methods, oral administration of hormones for Oreochromis niloticus has been reported to be the most preferred method in the commercial uses (Green and Teichert-Coddington, 2000; Cagauan et al., 2004, Wahby and Shalaby, 2010; and Celik et al., 2011). Oral administration of $17 \alpha$-methyltestosterone (MT) hormone is the most common and successful method used for producing all-male tilapia (Penman and McAndrew, 2000; Beardmore et al., 2001; and El-Sayed, 2006;). The hormone is generally 
incorporated into starter larval feed at 30-60 mg $\mathrm{MT} / \mathrm{kg}$ feed, during the critical period of sex differentiation.

The use of artificial incubation units involves the removal of eggs and sac fry from the mouth of females and incubating them artificially as an effective method of tilapia fry production. Net enclosures or hapas are also being used for the hatchery of tilapia (Guerrero, 1997). Hapas has many attributes that make them an excellent hatchery system for tilapia, especially in the developing countries (El-Sayed, 2006). These include easy construction, easy management, easy seed harvest and low cost. Hapas can also be suspended in fertilized earthen ponds, deep water bodies and concrete tanks supplied with clear water.

Currently in Egypt, the most hatcheries having incubation units started to reduce its using and began to depend upon the collected larvae from hapas or brood's mouth in hapas to decrease the hatchery costs. On the other hand, the used dose of hormone treatment increased from $60 \mathrm{mg} / \mathrm{kg}$ to $100-120 \mathrm{mg} / \mathrm{kg}$ in more than $75 \%$ of the Egyptian hatcheries. The intensive farming of tilapia is rapidly expanding and the need to produce sufficient quantities of high quality fry is becoming crucial to meet the increasing global demands for stocking tilapia farms.

The present study was conducted to evaluate the effects of larvae collecting system and treating with high dose of hormone on spawning efficiency and larvae quality as now applying in Egypt at a huge commercial scale.

\section{MATERIALS AND METHODS}

\section{Zoo-technical Methods:}

This study was conducted in a commercial hatchery at Shakshouk province, Fayoum Governorate, Egypt to evaluate the larval production systems for Nile tilapia applied in other commercial hatcheries on the spawning efficiency and quality of seed through two stages (spawning and larval rearing). The experiment extended during the period from 10 May, 2014 to 10 September, 2014.

\section{Spawning stage:}

One thousand and eight hundred broodstock were equally divided on fifteen hapa are placed in earthen pond (each measuring $5 \times 7 \times 0.7 \mathrm{~m}^{3}$ ). The broodstock were stocked at a sex ratio of 3 female to 1 male (30 male +90 Female) with an average weight of $125 \pm 7.8 \mathrm{~g} /$ fish. Broodstocks in hapas were fed on a commercial diet contained $29.89 \%$ protein (Hendrix Company) at a rate of $2 \%$ of body weight (Bhujel et al., 2007) two meals per day except the days of collecting of eggs or larvae .

Three treatments were tested. Each treatment represented by five hapas as follows :

- The first treatment: The eggs were collected from the mouth of female every 12 days and placed in the hatching laboratory and then fry estimated as weight, length and number in each hapa, then weighed $550 \mathrm{~g}$ of them and transported to the fry's hapas in an area of $2 \times 4 \mathrm{~m}$, then fed diet treated with hormone .

- The second treatment: The larvae were collected from hapa every 12 days quietly and without any disturbance for the broodstock in hapa, then weighed and measured for the length and weight of the larva and then placed in the fry's hapas at the same previous rate that was used in treatment 1 .

- The third treatment: The larvae were collected every 4-5 days from the mouth of each female by testing each female and leaving each female having eggs in mouth to the next collection and the collected larvae weighed and is estimated to the average weight and length and then placed in the fry's hapas at the same previous stocking rate.

\section{Larval rearing stage:}

Fish fry were fed on a diet containing $42.42 \%$ crude protein (CP)consisting of $30 \%$ Herring fish meal and $70 \%$ commercial diet(Hendrix company), plus $100 \mathrm{mg} / \mathrm{kg}$ diet from $17 \alpha$ methyl testosterone and fed seven times/day with a feeding rate of $20 \%$ of its weight for 21 days.

At the end of the experiment, the identification of the phenotypic sex for200juvenile fish from each treatment was determined by microscopic examination of the gonads when the fish reached 4-5 g. The thin gonad (thread-like structure lies along the dorsal side of the abdominal cavity) was extracted very carefully, placed on a glass slide and stained with a drop of aceto-carmine stain then it was lightly squashed with a glass cover slip and examined at $10 \mathrm{X}$ magnification for the identification of the juvenile gonads. The fish was a presumptive male and female if densely packed oocytes were found as reported by Guerrero and Shelton (1974).

Diets used during the broodstock and fry treatments were analyzed for their proximate composition in triplicates following the methods described by AOAC (1999). Water temperature, $\mathrm{pH}$, dissolved oxygen (DO), total ammonia $\left(\mathrm{NH}_{3}-\mathrm{N}\right)$, and salinity throughout the experimental period were measured periodically in the morning and at noon by centigrade thermometer, Orion digital $\mathrm{pH}$ meter model 201, oxygen meter, Cole Parmer model 5946, $\mathrm{HACH}$ test kit ammonia mid-range $0-3 \mathrm{mg} / \mathrm{L}$ model NI-8, respectively.

\section{Statistical Analysis:}

Data were statistically analyzed using a one-way analysis of variance using SPSS (2007) version 16. Mean of treatments were compared by Duncan multiple range test when the differences were significant.

\section{RESULTS AND DISCUSSIONS}

\section{Water quality:}

Results in Table (1) show the water quality parameters measured during the study in fish hapas. Mean values ( \pm SE) of water quality parameters were recorded as follows: dissolved oxygen DO 5.6 \pm 0.10 
$\mathrm{mg} / \mathrm{L}, \mathrm{pH} 8.0 \pm 0.18$, water temperature $29 \pm 0.96{ }^{\circ} \mathrm{C}$, $\mathrm{NH}_{3}-\mathrm{N} \quad 0.2 \pm 0.10 \mathrm{mg} / \mathrm{L}$ and salinity $1.4 \pm 0.10 \mathrm{ppt}$ respectively. These values were within the safe ranges and acceptable for the spawning and growth of tilapia as reported by El-Sayed (2006), Magid and Babiker (1975), Ross (2000) and El-Sherif and ElFeky (2008).

Table 1. Water quality parameters (Mean \pm S.E.) measured during the experiment

\begin{tabular}{lccccc}
\hline \multicolumn{1}{c}{ Item } & $\begin{array}{c}\mathrm{DO}, \\
\mathrm{mg} / \mathrm{L}\end{array}$ & $\mathrm{pH}$ & $\begin{array}{c}\text { Temp., } \\
{ }^{\circ} \mathrm{C}\end{array}$ & $\begin{array}{c}\mathrm{NH}_{3}-\mathrm{N}, \\
\mathrm{mg} / \mathrm{L}\end{array}$ & $\begin{array}{c}\text { Salinity, } \\
\% \mathrm{O}\end{array}$ \\
\hline First month & $5.7 \pm 0.29$ & $8.0 \pm 0.21$ & $28 \pm 0.81$ & 0.2 & $1.3 \pm 0.11$ \\
Second month & $5.6 \pm 0.28$ & 8.00 .21 & $29 \pm 0.80$ & 0.2 & $1.5 \pm 0.10$ \\
Third month & $5.5 \pm 0.27$ & 8.00 .20 & $30 \pm 0.82$ & 0.2 & $1.4 \pm 0.11$ \\
Forth month & $5.5 \pm 0.27$ & 8.00 .21 & $28 \pm 0.81$ & 0.2 & $1.5 \pm 0.13$ \\
Mean + S.E & $5.6 \pm 0.10$ & $8.0 \pm 0.18$ & $29 \pm 0.96$ & $0.2 \pm 0.10$ & $1.4 \pm 0.10$ \\
\hline
\end{tabular}

Spawning efficiency:

Results of spawning efficiency of Nile tilapia $O$. niloticus broodstocks under different larval collecting system are presented in Table 2 . The results indicate that there were significant $(\mathrm{P} \leq 0.05)$ differences between treatments and larval collecting system from brood's mouth exhibited a significantly higher spawning performance than those collected from hapas or hatching laboratory, on larval weight (g/hapa), larval number (pcs/hapa), number of spawned females and the frequency of spawning per female. The spawning intervals (days) increased by approximately 196 and $148 \%$ for brood's mouth compared with hapas and hatching laboratory, respectively. On the other hand, absolute fecundity improved significantly with larvae collected from hatching laboratory. compared with those collected from hapas and brood's mouth. Therefore, the total fry production of a hatchery collecting larvae from brood's mouth and contains 40 hapas was higher than other hatcheries depended on collecting larvae from hapas or hatching Lab. by 197.5 and $148 \%$, respectively. FCR values during larval rearing period improved significantly for larvae collected from brood's mouth compared with hapas and hatching laboratory larvae. The results show significant improvement of spawning performance with larvae collected from brood' mouth system every 4-5 days than that collected directly from hapas or incubated egg in hatching laboratory every 10-12 days. This may be due to short time intervals between collection from brood' mouth which encourage the broodstock to inter to next spawning stage than hapas or hatching laboratory leading to an increase in the number of larvae collected from mouth by about 196 and 148\% than other systems from hapa or lab., respectively. Larvae number/female/year was 2222, 1680 and 3298 larvae for collecting systems from hatching laboratory, hapas and brood's mouth, respectively. The spawning performance of female Nile tilapia observed in the present study is generally within the range of values or higher than that reported by other hatching laboratories based on the breeding experiments (Santiago and Reyes, 1993; Gunasekera et al., 1996; Campos-Mendosa et al., 2004; El-Sayed et al., 2005; SBRT 2007; El-Sayed and Kawanna, 2008; Lupatsch et al., 2010, Naiel et al., 2011 and Nasr-Allah et al., 2014) and less than that obtained by $\mathrm{Ng}$ and Wang (2011). However, any direct comparison with results from other studies should consider the differences in tilapia strains and experimental conditions used. Over the period of 4 months, larval collecting system using brood's mouth was the best in larvae number per hapa and per fish compared with the other larval collecting systems. However, the observed absolute fecundity did not significantly differ among the tested systems. The higher larvae production from brood's mouth was therefore due to increased spawning frequency, shorter inter spawning intervals and greater number of spawned females.

Table 2. Spawning efficiency of Nile tilapia (O. niloticus) brood-stocks under different larval collecting systems

\begin{tabular}{lccc}
\hline \multicolumn{1}{c}{ Item } & \multicolumn{3}{c}{ Larval collecting system } \\
\cline { 2 - 4 } & Laboratory & Hapa & Mouth \\
\hline Larvae weight, g/hapa & $2222^{\mathrm{b}} \pm 89.6$ & $1680^{\mathrm{c}} \pm 126.5$ & $3298^{\mathrm{a}} \pm 119.3$ \\
Larvae number, fry/hapa & $202474^{\mathrm{b}} \pm 8136$ & $152595^{\mathrm{c}} \pm 1152$ & $299981^{\mathrm{a}} \pm 1084$ \\
No of spawned Female & $292^{\mathrm{b}} \pm 11.79$ & $227^{\mathrm{c}} \pm 17.09$ & $446^{\mathrm{a}} \pm 16.12$ \\
Spawning frequency, number/female & $3.25^{\mathrm{b}} \pm 0.13$ & $2.52^{\mathrm{c}} \pm 0.19$ & $4.95^{\mathrm{a}} \pm 0.18$ \\
Feed consumed, g/hapa & 25000 & 25000 & 25000 \\
FCR * & $11.25^{\mathrm{b}} \pm 0.45$ & $14.88^{\mathrm{a}} \pm 1.11$ & $7.58^{\mathrm{c}} \pm 0.26$ \\
Spawning intervals, days & $37^{\mathrm{b}} \pm 1.48$ & $49^{\mathrm{a}} \pm 3.57$ & $24^{\mathrm{c}} \pm 0.51$ \\
Absolute fecundity & $693^{\mathrm{a}} \pm 7.68$ & $672^{\mathrm{b}} \pm 10.68$ & $673^{\mathrm{b}} \pm 18.95$ \\
Total hatchery production per thousand & 8099 & 6104 & 11999 \\
\hline \multicolumn{2}{c}{ Results are the mean \pm S.E. Values in the same row with different superscripts are significantly different $(\mathrm{P} \leq 0.05)$} \\
*Feed conversion ratio $=$ feed consumed/total larvae weight (As feed turns into fry)
\end{tabular}

\section{Sex reversal efficiency:}

Results of sex reversal efficiency as affected by larval collecting systems are illustrated in Table 3.
The results show that the highest percentage of male was obtained for larvae collected from brood's mouth $(96.61 \%)$ followed by larvae collected from hatching 
laboratory $(96.15 \%)$ and larvae collected from hapa $(90.33 \%)$. However, analysis of variance on the percentage of male indicated that there was no significant difference $(\mathrm{P} \leq 0.05)$ among larvae collected from brood's mouth and hatching laboratory but significantly higher than that collected from hapas. Percentage of males among the tested treatments were similar to the findings of Vera Cruz and Mair (1994). The androgen had no significant effect on growth and survival of fry during the treatment period and produced sex conversal rate of $94.36 \%$ male in hapas. Macintosh et al. (1988) reported a sex conversion of $95.7 \%$ and $92.8 \%$ in their experimental units stocked with methyltestosterone-treated fry.

Decreased male $\%$ of larvae collected from hapa $(90.33 \%)$ may be due to presence of natural food in the water of hapa especially in Egypt where all fish farms based on agricultural drainage water rich in natural foods. Also, larvae collected from hapas system every 10-12 day have high probability to contain multi ages of larvae more than other systems with a high probability to begin feeding on natural foods in hapa before collecting. Thus, the larvae treated with hormone under hapas treatment was less effective than the other treatments.

Table 3. Sex reversal efficiency as affected by larval collecting system

\begin{tabular}{ccccc}
\hline \multirow{2}{*}{ Item } & $\begin{array}{c}\text { No } \\
\text { examined }\end{array}$ & Male $\%$ & Female $\%$ & Intersex \% \\
\hline Larvae collected from laboratory & 184 & $96.15^{\mathrm{a}} \pm 0.16$ & $2.72^{\mathrm{b}} \pm 0.23$ & 1.09 \\
Larvae collected from hapa & 172 & $90.33^{\mathrm{b}} \pm 4.06$ & $7.56^{\mathrm{a}} \pm 0.82$ & 2.33 \\
Larvae collected from brood's mouth & 204 & $96.61^{\mathrm{a}} \pm 0.06$ & $2.45^{\mathrm{b}} \pm 0.16$ & 0.98 \\
\hline
\end{tabular}

Results are the mean \pm S.E.

Values in the same column with different superscripts are significantly different $(\mathrm{P} \leq 0.05)$

\section{Growth performance and survival rate (\%)of larvae:}

Larval growth performance parameters are illustrated in Table 4 which show significant differences $(\mathrm{P} \leq 0.05)$ between treatments on average weight at stocking, weight at the end of the experiment (21 days), weight gain, SGR and FCR. The growth performance for larvae collected from hapas was higher than other larval collecting systems. Number of larvae at harvesting/ hapa and at starting was significant different $(\mathrm{P} \leq 0.05)$ but survival rate was insignificant.

The condition factor for $O$. niloticus larvae was1.28, 1.24 and 1.26 after larval collection and $1.81,1.65$ and 1.62 after sex reversal period for larvae collected from hatching laboratory, hapas and brood's mouth, respectively. Results in Table 4 shows that both larval length and weight after sex reversal were significantly $(\mathrm{P} \leq 0.05)$ lower with larvae collected from hatching Lab. than for larvae obtained from hapa and brood's mouth. There were no significant $(\mathrm{P}>\leq 0.05)$ differences in length at the start. The values of growth performance were obtained through the experiment from hapas treatment showed higher values compared to the larvae from laboratory or brood's mouth. These results may be due to the fact that larvae from hapa don't hatched in the same day but in different days and age was different and became high in weight than larvae from lab which hatched in the same day. However, larvae obtained from brood's mouth was in between because the larvae was taken from mouth or hatched in a previous day.

Table 4. Growth performance and survival rate (Mean \pm S.E.) of larvae produced under different larval collecting systems

\begin{tabular}{lccc}
\hline \multirow{2}{*}{\multicolumn{1}{c}{ Item }} & \multicolumn{3}{c}{ Larval collecting system } \\
\cline { 2 - 4 } & Laboratory & Hapa & Broods's mouth \\
\hline Number of larvae at stocking/hapa & $202474^{\mathrm{b}} \pm 8136$ & $152595^{\mathrm{c}} \pm 1152$ & $299981^{\mathrm{a}} \pm 1084$ \\
Number of larvae at harvesting/hapa & $182228^{\mathrm{b}} \pm 7444$ & $137340^{\mathrm{c}} \pm 10166$ & $269978^{\mathrm{a}} \pm 11271$ \\
Survival rate, \% & $90.00 \pm 0.161$ & $90.00 \pm 0.592$ & $90.00 \pm 0.853$ \\
Larvae weight at start, mg & $10.97^{\mathrm{c}} \pm 0.008$ & $11.01^{\mathrm{a}} \pm 0.007$ & $10.99^{\mathrm{b}} \pm 0.007$ \\
Larvae weight at end, mg & $97.90^{\mathrm{c}} \pm 0.05$ & $110.46^{\mathrm{a}} \pm 0.27$ & $103.61^{\mathrm{b}} \pm 0.13$ \\
Weight gain, mg & $86.93^{\mathrm{b}} \pm 0.04$ & $99.45^{\mathrm{a}} \pm 0.27$ & $92.62^{\mathrm{b}} \pm 0.13$ \\
SGR* & $10.42^{\mathrm{c}} \pm 0.002$ & $10.98^{\mathrm{a}} \pm 0.011$ & $10.68^{\mathrm{b}} \pm 0.005$ \\
Larvae length at start, mm** & $9.5 \pm 0.04$ & $9.62 \pm 0.03$ & $9.56 \pm 0.04$ \\
Larvae length at end, mm & $17.54^{\mathrm{c}} \pm 0.02$ & $18.84^{\mathrm{a}} \pm 0.05$ & $18.58^{\mathrm{b}} \pm 0.03$ \\
Condition factor at start & $1.28 \pm 0.02$ & $1.24 \pm 0.01$ & $1.26 \pm 0.01$ \\
Condition factor at end & $1.81^{\mathrm{a}} \pm 0.01$ & $1.65^{\mathrm{b}} \pm 0.01$ & $1.62^{\mathrm{c}} \pm 0.01$ \\
Feed consumed, mg/larvae & 72.92 & 72.92 & 72.92 \\
FCR (for growth) $* * *$ & $0.84^{\mathrm{a}} \pm 0.001$ & $0.73^{\mathrm{c}} \pm 0.002$ & $0.79^{\mathrm{b}} \pm 0.001$ \\
\hline
\end{tabular}

Values in the same row with different superscripts are significantly different $(\mathrm{P} \leq 0.05)$

$*$ Specific growth rate $=[(\ln$ final fish weight $-\ln$ initial fish weight $) /$ time $] \times 100$.

$* *$ Condition factor $=100 \times \mathrm{W} / \mathrm{L}^{3}$, where $\mathrm{W}$ is the fish weight $(\mathrm{g})$, and $\mathrm{L}$ is the total length of fish $(\mathrm{cm})$.

$* * *$ Feed conversion ratio $=$ feed consumed/total larvae weight $($ As feed turns into fry) 


\section{Economic efficiency:}

The economic efficiency of the tilapia hatcheries that are applying these systems and containing 40 hapas of broodstocks $(3600$ q $+1200 \quad$ o $)$ is illustrated in Table 5. Total costs of each hatchery was different according to their equipment. Larvae hatched in laboratory was higher in costs and fry sales price than other systems. The net returns from each hatchery was higher with brood' mouth collecting system followed by hatching laboratory and hapas systems. This study shows that if larvae are collected from brood's mouth every 4-5 days in a hatchery contained 4800 broodstock (40 hapa) will produce about 10.799 million fry after sex reversal in a spawning season. Total costs were 215,000; 104,000 and $113,000 \mathrm{LE} /$ hatchery for the larval collecting systems from hatching laboratory, hapas and brood's mouth, respectively. These results reveal that the total cost of hatchery contains laboratory was the highest than other systems. On the other hand, the total cost of hatchery based on larvae collected from hapa (without lab) was the lowest due to the absence of lab and less labor costs. Net returns in LE per hatchery were 78,$564 ; 25,872$ and 106,982 for the larvae collected from laboratory, hapa and brood's mouth, respectively. Percentages of net return to total cost were $36.54 ; 24.88$ and $94.67 \%$ for hatchery collected larvae from laboratory, hapas and brood's mouth, respectively. The results indicated that the highest net returns were obtained with the larval collecting system from brood's mouth.

Table 5. Economic efficiency of tilapia hatcheries applied different larval collecting systems

\begin{tabular}{|c|c|c|c|}
\hline \multirow{2}{*}{ Item } & \multicolumn{3}{|c|}{ Larval collecting system } \\
\hline & Hatching laboratory & Hapa & Brood's mouth \\
\hline \multicolumn{4}{|l|}{ Hatchery costs, LE* } \\
\hline Brood & 25,000 & 25,000 & 25,000 \\
\hline Feed & 28,000 & 24,000 & 33,000 \\
\hline Equipmentand apparatus & 112,000 & 27,000 & 27,000 \\
\hline Other (land, labors) & 50,000 & 28,000 & 28,000 \\
\hline Total costs & 215,000 & 104,000 & 113,000 \\
\hline \multicolumn{4}{|l|}{ Selling fry, LE } \\
\hline Mono sex fry & 291564 & 109872 & 215982 \\
\hline Mixed fingerlings & 2000 & 20000 & 4000 \\
\hline Total sales & 293564 & 129872 & 219982 \\
\hline Net returns/hatchery, LE & 78,564 & 25,872 & 106,982 \\
\hline Net returns/total costs $\%$ & 36.54 & 24.88 & 94.67 \\
\hline
\end{tabular}

* U.S.\$ $=7.4 \mathrm{LE}$

Price of 1000 fry was 40 LE for hatching Lab and 20 LE form hapa and brood's mouth

\section{Sensitivity analysis:}

Sensitivity analysis was performed to measure the financial performance of the three larval collecting systems in the case of increasing total costs and decreasing sales prices (Table 6). There are critical threats facing hatcheries during spawning season, particularly the increasing cost of feed, fuel and labor costs. Also, sales prices have decreased over the years, probably due to increasing competition between hatcheries. The system of larval collection from brood's mouth is more stable in positive case compared to other systems that were less stable. Sensitivity analysis showed that the three larval collecting systems would still generate positive net returns even if sales prices decreased by $10 \%$ and variable costs increased by $10 \%$. However when sales prices decreased $30 \%$ and total costs were increased by $30 \%$, only the larvae collected from brood's mouth system could still be positive, while the larval collecting systems from lab and hapa showed losses. Hatcheries collected larvae from hapa appears more affected by increasing total costs or decreasing sales prices for more than $20 \%$ but hatcheries using larvae collected from lab are in between. These results are in agreement with the results obtained by Green et al. (2002) who found that a $20 \%$ reduction in fish selling prices for Egyptian fish farmers resulted in negative net returns indicating that hatcheries are more tolerant to financial shocks than grow-out fish farms. 
Table 6. Sensitivity analysis of changes in sales prices and total costs on net returns per hatchery (LE/season)

\begin{tabular}{|c|c|c|c|c|c|}
\hline \multirow{2}{*}{$\begin{array}{l}\text { Larvae collected } \\
\text { system }\end{array}$} & \multirow{2}{*}{$\begin{array}{c}\text { Change in sales } \\
\text { price }\end{array}$} & \multicolumn{4}{|c|}{ Changes in total costs } \\
\hline & & 0 & +10 & +20 & +30 \\
\hline Laboratory & 0 & 78.564 & 57.064 & 35.564 & 14.064 \\
\hline Hapa & 0 & 25.872 & 15.472 & 5.072 & -5.328 \\
\hline Brood's mouth & 0 & 106.982 & 95.682 & 84.382 & 73.082 \\
\hline Laboratory & -10 & 49.208 & 27.708 & 6.208 & -15.292 \\
\hline Hapa & -10 & 12.885 & 2.485 & -7.915 & -18.315 \\
\hline Brood's mouth & -10 & 84.984 & 73.684 & 62.384 & 51.084 \\
\hline Laboratory & -20 & 19.851 & -1.649 & -23.149 & -44.649 \\
\hline Hapa & -20 & -0.102 & -10.502 & -20.902 & -31.302 \\
\hline Brood's mouth & -20 & 62.986 & 51.686 & 40.386 & 29.086 \\
\hline Laboratory & -30 & -9.505 & -31.005 & -52.505 & -74.005 \\
\hline Hapa & -30 & -13.09 & -23.49 & -33.89 & -44.29 \\
\hline Brood's mouth & -30 & 40.987 & 29.687 & 18.387 & 7.087 \\
\hline
\end{tabular}

\section{CONCLUSIONS}

In conclusion, larval collecting system from brood's mouth every 4-5 day was the best on basis of spawning efficiency, high sex reversal rate and economic efficiency than larvae collected from hapas and this system can be applied easy in any hatchery.

\section{REFERENCES}

AOAC, Association of Official Analytical Chemists, 1999. Official Methods of Analysis of AOAC, $16^{\text {th }}$ ed. AOAC International, Washington, DC. USA.

Beardmore, J.A., G.C. Mair, R.I. Lewis, 2001. Monosex male production in finfish as exemplifiedby Tilapia: applications, problems and prospects. Aquaculture 197,283-301.

Bhujel, R.C., D.C. Little and A. Hossain, 2007. Reproductive performance and the growth of prestunted and normal Nile tilapia (Oreochromis niloticus) broodfish in varying feeding rates. Aquaculture 273, 71-79.

Cagauan A.G., F.N. Baleta and J.S. Abucay, 2004. Sex reversal of Nile tilapia, Oreochromis niloticus by egg immersion technique: The effect of hormone concentration and immersion time. In: $6^{\text {th }}$ International Symposium on Tilapia in Aquaculture Philippine International Convention Center Roxas Boulevard, Manila, Philippines. pp. 127-136.

Campos-Mendoza, A., B.J. McAndrew, K. Coward and N. Bromage, 2004. Reproductive response of Nile tilapia (Oreochromis niloticus) to photoperiodic manipulation; effects on spawning periodicity, fecundity and egg size. Aquaculture, 231: 299-314.

Celik, I., Y. Guner and, P. Celik, 2011. Effect of orally-administered $17 \alpha$ methyltestosterone at different doses on the sex reversal of the Nile tilapia (Oreochromis niloticus, Linneaus 1758). Journal of Animal and Veterinary Advances 10 (7), 853-857.

Duncan, D.B., 1955. Multiple range and multiple F tests. Biometrics 11: 1-42
El-Sayed, A.F.M., 2006. Tilapia culture. CAB International, Wallingford, UK, ISBN-13: 978-085199-014-9, Pages: 304

El-Sayed, A.F.M. and M. Kawanna, 2008. Effects of dietary protein and energy levels on spawning performance of Nile tilapia (Oreochromis niloticus) broodstock in a recycling system. Aquaculture 280, 179-184.

El-Sayed, A.F.M., C.R. Mansour and A.A. Ezzat, 2005. Effects of dietary lipid source on spawning performance of Nile tilapia (Oreochromis niloticus) broodstock reared at different water salinities. Aquaculture 248, 187-196.

El-Sherif, M. S. and A.M. EL-Feky, 2008. Effect of ammonia on Nile Tilapia (O. niloticus) performance and some hematological and histological measures. $8^{\text {th }}$ International Symposium on Tilapia in Aquaculture. Cairo, Egypt.

FAO, 2012. Food and Agriculture Organization of the United Nations. Statistics and Information Service Fisheries and Aquaculture Department. The State of World Fisheries and Aquaculture part 1

FAO, 2014. Food and Agriculture Organization of the United Nations The State of World Fisheries and Aquaculture Opportunities and challenges. Rome,

GAFRD, 2012. General authority for fish resources development. Fishery statistic. Egyptian Ministry of Agriculture. Year Book. Ministry of Agriculture and Land Reclamation Publications, Cairo, Egypt, Pages: 106

Green, B.W., Z. El Nagdy and H. Hebicha, 2002. Evaluation of Nile tilapia pond management strategies in Egypt. Aquacult. Res. (33), 10371048

Green, B.W. and D.R. Teichert-Coddington, 2000. Human food safety and environmental assessment of the use of $17 \alpha$-methyltestosterone to produce male tilapia in the United States. Journal of World Aquaculture Society 31, 337-357. 
Guerrero, R. D., 1997. A guide to tilapia farming. Aquatic Biosystems. Bay, Laguna, Philippines. 70 pp.

Guerrero, R.D. and W.L. Shelton, 1974. An acetocarmine squash method for sexing juvenile fishes. Prog. Fish-Cult., 36: 56.

Gunasekera, R.M., K.F. Shim, and T.J. Lam, 1996. Effect of dietary protein level on spawning performance and amino acid composition of eggs of Nile tilapia (Oreochromis niloticus). Aquaculture 146, 121-134.

Lupatsch, I., R. Deshev and I. Magen, 2010. Energy and protein demands for optimal egg production including maintenance requirements of female tilapia Oreochromis niloticus. Aquac. Res. 41, 763-769.

Macintosh, D. J., T.B. Singh, D.C. Little and P. Edwards, 1988. Growth and sexual development of 17 alpha-methyltestosterone- and progesterone-treated Nile tilapia (Oeochomis niloicus) reared in earthen ponds. p. 457-463. In: R.S.V.

Magid, A. and M.M. Babiker, 1975. Oxygen consumption and respiratory behaviour of three Nile fishes. Hydrobiologia 46: 359-367.

Naiel, R.A., M.G. Aamer, A.A. Ibrahim and G.E. Azazy, 2011. Economics of fry production of fish hatcheries. Zagazig J. Agric. Res. 38 (5), 13291341.

Nasr-Allah, A.M., M. Dickson, D.A. Al-Kenawy, M.F. Mohamed and G. El Naggar, 2014. Technical characteristics and economic performance of commercial tilapia hatcheries applying different management systems in Egypt. Aquaculture (426-427) 222-230.

$\mathrm{Ng}, \mathrm{W} . \mathrm{K}$. and Y. Wang, 2011. Inclusion of crude palm oil in the broodstock diets of female Nile tilapia, Oreochromis niloticus, resulted in enhanced reproductive performance compared to broodfish fed diets with added fish oil or linseed oil. Aquaculture 314: 122-131

Penman, D.J. and B.J. Mc-Andrew, 2000. Genetics for the management and improvement ofcultured tilapia. In: Beveridge,M.C.M. and McAndrew, B.J. (Eds.), Tilapias: Biology and Exploitation.Kluwer Academic Publishers, Dordrecht/Boston/London, pp. 227-266.

Ross, L.G., 2000. Environmental physiology and energetics. pp. 89-128. In: M. C. M. Beveridge and B. J. McAndrew (eds.) Tilapias: Biology and Exploitation, Fish and Fisheries Series 25, Kluwer Academic Publishers, Dordrecht, The Netherlands.

Santiago, C.B. and O.S. Reyes, 1993. Effects of dietary lipid sources on reproductive performance and tissue lipids of Nile tilapia. SEAFDEC Asian Aquaculture, Vol. XIV, No. 4, December 1993, 5-7 pp.

SBRT, 2007. Servic,o Brasileiro de Respostas Te'cnicas: \http://sbrt.ibicit.br/ uploa/sbit1615 [cited: June

SPSS, 2007. Statistical Package For Social Science (for Windows). Release 16 Copyright(C), SPSS Inc., Chicago, USA.

Vera Cruz, E.M., and G.C. Mair 1994. Conditions for effective androgen sex reversal in Oreochromis niloticus (L.) Aquaculture 112:137-248.

Wahby, O.M. and S.H. Shalaby, 2010. Oral administration of testosterone in fish diet affect sex differentiation and testis development in tilapia. Research Journal of Agriculture and Biological Sciences 6 (6): 946-952.

\section{تأثير نظام جمع اليرقات على كفاءة التفريخ وجودة الزريعة المحولة جنسيا فى مفرخات اسماك البلطى}

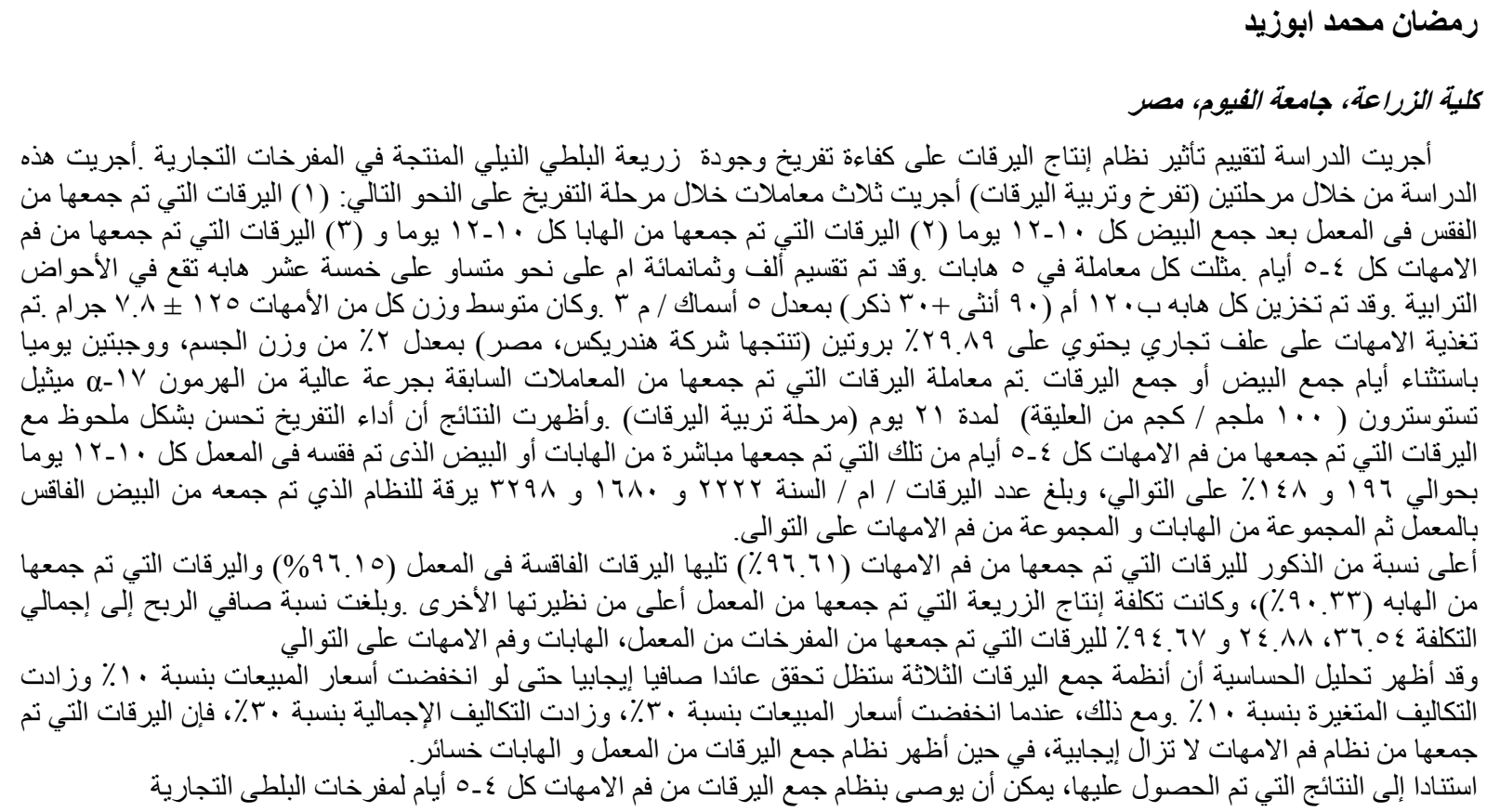

